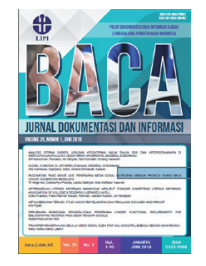

\title{
Peran gawai mobile dalam mendukung layanan informasi perpustakaan digital yang terpersonalisasi
}

\author{
Shiddiq Sugiono \\ Pusat Penelitian Ilmu Pengetahuan dan Teknologi, Kemenristek/BRIN \\ Korespondensi: sugionoshiddiq@gmail.com
}

Diajukan: 03-03-2021; Direview: 12-04-2021; Diterima: 18-05-2021; Direvisi: 31-05-2021

\begin{abstract}
Personalized information service is an information service delivered by digital libraries so that users can only get information according to their needs online. This article is a conceptual study that examines the role of mobile devices as technology to support personalized information services from the aspects of user data collection and service delivery. Data obtained through literature review of scientific articles that have relevance to the main concept. The results showed that mobile devices have a role in sending data and accessing library services efficiently. As a two-way communication medium, mobile devices can send various forms of feedback to the library which eventually become data for further analysis. As for service access, mobile devices can support mobile applications so that there are several traditional services that can be accessed online anywhere and anytime. Not only data in the form of text, technological developments have been able to analyze data in other types, one of which is in the form of voice. The development of technology in the 4.0 industrial revolution has also become an aspect that encourages efficiency because it can bring about automation in the aspects of data collection and access to library services.
\end{abstract}

\begin{abstract}
ABSTRAK
Layanan informasi terpersonalisasi merupakan suatu layanan informasi yang disampaikan oleh perpustakaan digital sehingga penggunanya hanya mendapatkan informasi yang sesuai dengan kebutuhannya secara daring. Artikel ini merupakan penelitian konseptual yang mengkaji bagaimana peran gawai mobile sebagai teknologi untuk mendukung layanan informasi terpersonalisasi dari aspek pengumpulan data pengguna dan penyampaian layanan. Data diperoleh melalui tinjauan literatur terhadap artikel ilmiah yang memiliki relevansi konsep utama. Hasil penelitian menunjukan bahwa gawai mobile memiliki peran dalam pengiriman data dan mengakses layanan perpustakan secara efisien. Sebagai media komunikasi dua arah, gawai mobile dapat mengirimkan berbagai macam bentuk feedback kepada perpustakaan yang akhirnya menjadi data untuk dianalisis lebih lanjut. Adapun dalam hal akses layanan, gawai mobile dapat mendukung aplikasi mobile sehingga terdapat berberapa layanan tradisional yang dapat diakses secara online dimanapun dan kapanpun. Tidak hanya data berupa teks saja, perkembangan teknologi telah mampu menganalisis data dalam jenis yang lain, salah satunya berupa suara. Perkembangan teknologi pada revolusi industri 4.0 turut menjadi aspek yang mendorong efisiensi karena mampu memunculkan otomatisasi dalam aspek pengumpulan data maupun akses layanan perpustakaan.
\end{abstract}

Keywords: Digital library; Personalized information; Mobile device; Information service; Library services

\section{PENDAHULUAN}

Informasi telah menjadi sumber daya utama yang dibutuhkan oleh manusia modern untuk dapat melanjutkan keberlangsungan hidupnya. Informasi merupakan basis dari sebuah pengetahuan yang pada akhirnya dapat membentuk manusia dan peradaban yang cerdas (Li, Lizhen, \& Yue, 2007). Sesuai dengan definisi informasi yang disampaikan oleh Rowley (2007), informasi dapat membantu seseorang untuk menjawab suatu pertanyaan yang dimulai dari kata tanya apa, siapa, kapan serta berapa banyak. Melalui informasi kita dapat mengetahui dan memahami secara jelas mengenai apa yang sebenarnya terjadi dalam suatu dinamika kehidupan. 
Informasi yang akurat dan berkualitas turut menjadi suatu komponen penting dari terciptanya keputusan yang berkualitas (Houhamdi \& Athamena, 2019). Gbotosho (2019) menyampaikan bahwa informasi telah menjadi sumber daya strategis yang merubah perekonomian dunia. Gagasan tersebut memberikan implikasi bahwa saat ini suatu informasi yang berkualitas harus dapat diakses, dicari maupun didapatkan secara mudah dan cepat oleh manusia agar terus muncul berbagai pengetahuan baru yang berguna bagi kehidupan manusia.

Perpustakaan, baik tradisional maupun digital, adalah sebuah institusi yang mengemban tanggung jawab dalam hal penyediaan dan penyebaran informasi bagi individu-individu yang membutuhkannya. Perpustakaan harus mampu meyakinkan setiap individu bahwa pustakawan mampu mencari dan memenuhi kebutuhan informasi dari setiap individu melalui berbagai cara (Stojanovski \& Papić, 2012). Selain itu, perpustakaan harus mampu memberikan layanan referensi akademis bagi masyarakat karena saat ini banyak informasi yang tersedia dan dapat disadur secara langsung melalui internet tanpa tahu kredibilitas dan kualitasnya (Tutu, 2016). Li, Lizhen, \& Yue (2007) turut menyampaikan bahwa perpustakaan harus mampu melakukan diversifikasi pada layanannya, tidak hanya sebagai penyedia informasi saja namun harus mampu memberikan layanan konsultasi referensi, penyediaan sumberdaya multimedia, layanan suara, layanan email dan lain sebagainya. Berdasarkan tugas-tugasnya, perpustakaan dinilai menjadi bagian penting dari terbangunnya peradaban manusia yang cerdas dan modern sehingga muncul urgensi untuk terus meningkatkan kualitas layanannya.

Pada dasarnya layanan perpustakaan hadir untuk memenuhi kebutuhan informasi, saat ini muncul suatu tantangan baru bahwa perilaku manusia bersifat heterogen tergantung pada ruang dan waktu sehingga membuat kebutuhan informasi dari pengguna perpustakaan menjadi lebih kompleks bahkan berubah-ubah (Wang, 2016). Adapun besarnya volume informasi di internet saat ini menyebabkan aktivitas pencarian dan seleksi informasi yang sesuai dengan kebutuhan memakan banyak waktu sehingga hal ini menjadi tidak efisien (Li, Lizhen, \& Yue, 2007). Pang \& Yan (2012) menyampaikan bahwa disamping mendapatkan kenyamanan dalam menggunakan perpustakaan digital para pengguna perpustakaan tersebut menderita dengan banyaknya dan beragamnya sumber daya informasi padahal setiap informasi memiliki nilai yang berbeda di benak satu individu. Gbotosho (2019) menyampaikan dimana ledakan informasi saat ini menjadikan seseorang harus mendapatkan informasi yang relevan dengan waktu dan biaya yang minimum tanpa terbebani dengan informasi yang tidak relevan dalam jumlah besar. Berbagai tantangan tersebut menjadi permasalahan yang harus dijawab oleh penyedia jasa layanan informasi, atau dalam hal ini perpustakaan, sehingga pada akhirnya masyarakat mampu menciptakan pengetahuan-pengetahuan dengan cara yang lebih efektif dan efisien.

Layanan informasi terpersonalisasi (personalized information service) merupakan sebuah layanan perpustakaan yang telah dipertimbangkan sebagai jalan keluar untuk menghadapi derasnya informasi di internet. Secara umum perpustakaan akan memberikan layanan berdasarkan informasi perilaku pengguna, kebiasaan, preferensi, karakteristik, kebutuhan spesifik dari satu pengguna (Pang \& Yan, 2012). Taylor \& Corrall (2007) mengatakan bahwa layanan informasi terpersonalisasi adalah solusi untuk menghadapi informasi yang berlebihan. Zhang \& Wang (2014) menjelaskan bahwa dalam ruang lingkup internet, sebagian besar pengguna tidak memiliki keahlian tinggi dalam melakukan pencarian informasi yang benar-benar dibutuhkan dan mereka tidak menggunakan jasa profesional dalam pencarian tersebut. Kesempatan bagi perpustakaan digital untuk membangun sistem yang ramah bagi penggunanya sehingga kebutuhan informasi dapat dipenuhi. Gagasan utama yang ingin disampaikan layanan terpersonalisasi ialah bahwa setiap orang akan mendapatkan pelayanan yang unik sesuai dengan kebutuhannya sehingga bisa memunculkan efisiensi baik dari sisi pelanggan dalam durasi mencari informasi maupun dari sisi perpustakaan dalam memberikan layanan informasi. 
Perkembangan teknologi di era revolusi industri 4.0 turut menjadi salah satu dukungan terhadap pengembangan layanan terpersonalisasi yang lebih baik kedepannya. Model bisnis suatu organisasi mulai berubah dimana pelanggan menjadi fokus dari pelayanan dan kolaborasi dengan pelanggan menjadi kunci untuk menyampaikan produk atau layanan terbaru (Bal \& Erkan, 2019). Pelanggan lebih menginginkan pengalaman yang personal dalam menggunakan sebuah layanan. Noh (2015) menjelaskan bahwa pengimplementasian teknologi big data dan data analytics adalah beberapa teknologi yang berguna memungkinkan suatu organisasi untuk merancang, membuat dan menyampaikan produk atau layanannya kepada pelanggan (Bal \& Erkan, 2019). Penyampaian layanan terpersonalisasi turut didukung oleh media komunikasi yang memungkinkan arus informasi dua arah, dimana media tersebut menjadi ciri khas revolusi industri 4.0 (Bal \& Erkan, 2019). Melalui komunikasi dua arah yang didukung oleh media, organisasi akan mendapatkan feedback dari pelanggan atas layanan yang diberikan sebagai dasar membuat layanan yang terbaru dan lebih baik.

Li, Lizhen, \& Yue (2007) merangkum empat signifikansi yang harus dipertimbangkan oleh perpustakaan untuk mengimplementasikan layanan yang bersifat personal. Pertama, layanan personal mendukung terciptanya pengembangan berkelanjutan dari perpustakaan tradisional. Kedua, merubah konsep perpustakaan dari publik menjadi individual sehingga memberikan kenyamanan kepada pengguna. Ketiga, menjadikan pengguna sebagai fokus layanan sehingga kepuasan menjadi target layanan informasi. Keempat, layanan personal adalah karakteristik utama dari perpustakaan generasi ketiga. Berbagai berbagai signifikansi tersebut pada akhirnya merujuk pada satu gagasan dimana layanan yang terpersonalisasi memberikan manfaat kepada setiap stakeholder tidak hanya perpustakaan sebagai penyedia layanan namun juga pengguna layanan tersebut sehingga menjadi suatu sistem yang harus dikembangkan oleh berbagai pemangku kepentingan.

Dalam memberikan layanan informasi terpersonalisasi perpustakaan dapat menggunakan media atau gawai yang bersifat mobile sehingga layanan tersebut dapat diakses oleh penggunanya dimanapun dan kapanpun mereka berada secara efisien (Jeevan \& Padhi, 2006). Buarki \& Dar (2019) menjelaskan bahwa dalam konteks universitas di negara Kuwait, gawai mobile paling banyak digunakan oleh mahasiswa dalam mengakses perpustakaan digital karena melalui gawai tersebut mereka dapat mengunduh berbagai sumber daya digital dimana salah satunya adalah artikel yang direkomendasikan oleh perpustakaan kapanpun mereka butuh. Wei \& Yang (2017) menyampaikan bahwa saat ini salah satu universitas di negara Tiongkok telah menggunakan media sosial sebagai media untuk mengakses layanan perpustakaan universitas. Sharman (2014) menjelaskan bahwa gawai mobile memungkinkan pustakawan untuk memberikan sumber daya digital yang terpersonalisasi sehingga hubungan mereka dengan pengguna menjadi lebih dekat.

Mobile digital library dapat dipandang sebagai solusi untuk menjawab tingginya mobilitas manusia saat ini dengan memanfaatkan gawai mobile. Mobile digital library mendukung cara baca mobile yang mampu memenuhi keinginan manusia modern akan efisiensi dan kesederhanaan/ simplicity (Ni \& Zhang, 2019). Cara baca melalui perpustakaan mobile tersebut dinilai akan segera menjadi cara baru yang digunakan oleh manusia untuk mendapatkan pengetahuan dan meningkatkan kualitas dirinya (Ni \& Zhang, 2019). Alfaresi \& Hone (2015) menyampaikan bahwa manfaat yang paling dirasakan oleh pengguna mobile digital library di negara Uni Emirat Arab adalah layanan yang dapat diakses di mana saja meskipun mobilitas mereka tinggi. Layanan yang dapat digunakan secara mobile turut menjadi salah satu variabel yang signifikan dalam mendorong niatan untuk menggunakan mobile digital library dalam konteks mahasiswa dan pekerja di Tiongkok (Liu et al., 2020). Berbagai argumen tersebut pada dasarnya menyampaikan hal yang sama dimana mobile digital library mampu menjadi solusi bagi kebutuhan informasi manusia meskipun mobilitas mereka tinggi. 
Gawai mobile (mobile devices) memiliki peran penting dalam tatanan ini. Meskipun layanan informasi yang disampaikan sudah mumpuni tetapi harus tetap disampaikan secara efektif dan efisien kepada pengguna layanannya. Personalisasi layanan merupakan aspek yang ingin dicari oleh pelanggan dalam suatu layanan di gawai mobile (Asif \& Krogstie, 2013). Gawai digital merupakan perangkat pribadi yang selalu dibawa bersama sepanjang waktu sehingga menjadikannya sebagai platform yang ideal untuk personalisasi (Asif \& Krogstie, 2012). Hal ini menandakan bahwa gawai mobile adalah alat dinilai yang secara efektif mampu memenuhi kebutuhan individu yang semakin bersifat pribadi dan bersifat fleksibel karena dapat diakses dimanapun dan kapanpun.

Berdasarkan hasil dari penelusuran literatur pada basis data Google Scholar maupun Scopus, fokus penelitian terhadap gawai mobile sebagai komponen dalam membentuk ekosistem layanan informasi terpersonalisasi secara konseptual belum dapat ditemukan. Kumar (2013) menggambarkan pentingnya memanfaatkan gawai mobile dalam layanan perpustakaan, namun tidak memfokuskan pada layanan terpersonalisasi. Zhang dan Wang (2014) memberikan rekomendasi mengenai strategi layanan yang dapat digunakan untuk melakukan layanan informasi terpersonalisasi pada sebuah perpustakaan digital tetapi tidak berfokus pada medianya. Ada tiga strategi utama dalam mengimplementasikan layanan informasi terpersonalisasi yaitu: membangun hubungan baik dengan pelanggan, fokus dalam integrasi dan interoperabilitas informasi, serta mengembangkan layanan terpersonalisasi dari berbagai aspek.

Taylor \& Corrall (2007) mengkaji mengenai persepsi pegawai pemerintah terhadap layanan informasi terpersonalisasi dalam perpustakaan di lembaga pemerintahan di Inggris. Li, Lizhen, \& Yue (2007) mengkaji mengenai alur kerja atau mekanisme yang menggambarkan layanan informasi terpersonalisasi oleh suatu perpustakaan digital serta skenario perpustakaan digital di masa depan. Pang \& Yan (2012) melakukan pengkajian mengenai suatu mekanisme yang memungkinan teknologi data mining dapat diimplementasikan dalam perpustakaan digital dan membahas pengaplikasian teknologi tersebut dalam bidang perpustakaan dimana salah aplikasinya adalah layanan informasi terpersonalisasi. Kajian ini akan memberikan kebaruan mengenai layanan informasi terpersonalisasi dalam fokus pemanfaatan gawai mobile untuk mengakses layanan perpustakan.

Berdasarkan argumentasi dan fakta empiris yang telah disampaikan maka dapat terlihat bahwa saat ini terdapat urgensi dimana suatu perpustakaan harus mulai berfokus pada pelanggan atau dalam hal ini mengadaptasi layanan informasi yang terpersonalisasi melalui gawai mobile. Penelitian ini menekankan pada bagaimana peran gawai mobile sebagai media yang digunakan untuk mengakses perpustakaan digital dalam mendukung ekosistem layanan informasi terpersonalisasi. Adapun pemanfaatan mobie digital library dan layanan informasi terpersonalisasi memiliki signifikansi positif baik kepada pihak perpustakaan maupun penggunanya. Penelitian ini bertujuan untuk memetakan berbagai peran mobile digital library untuk membangun ekosistem layanan terpersonalisasi. Pertanyaan yang sekaligus menjadi batasan dalam penelitian ini adalah sebagai berikut: sejauh apa peran yang dapat dimunculkan oleh perangkat mobile sebagai media untuk mengakses mobile digital library sehingga tercipta layanan informasi terpersonalisasi yang efektif dan efisien dalam suatu layanan perpustakaan?

\section{TINJAUAN PUSTAKA}

\subsection{Mobile Digital Library}

Pendalaman konsep mengenai mobile digital library akan dimulai dengan penjelasan mengenai konsep digital library itu sendiri. Digital library merupakan kumpulan sumber daya elektronik yang terdiri atas teks, suara, visual, grafis dan animasi yang dapat diakses melalui bantuan teknologi digital (Gbotosho, 2019). Sumber daya yang berada pada digital library dapat diakses secara langsung, dimana pengguna dapat mengakses sumber daya yang sudah berformat digital, maupun tidak 
langsung, dimana sumber daya masih berformat analog tetapi terdapat metadata yang dapat diakses secara elektronik (Prasetyo, et al., 2016). Li, Lizhen, \& Yue (2007) menyampaikan bahwa salah satu karakteristik dari digital library adalah sistem yang mengorganisir informasi sehingga mudah dicari dan digunakan oleh pengguna. Hal ini menunjukan bahwa melalui teknologi informasi dan komunikasi, perpustakaan sudah mulai berinovasi dari segala bidang tidak hanya dari layanannya bahkan sampai kepada model bisnisnya.

Kao \& Wu (2012) menyampaikan bahwa digital library harus menjadi sebuah saluran yang berguna untuk berbagi pengetahuan sehingga dapat meningkatan performa belajar masyarakat. Li, Lizhen, \& Yue (2007) menyampaikan bahwa digital library tidak hanya membuat perpustakaan tradisional menjadi digital atau membuat sumber fisik menjadi digital, tetapi sebuah layanan informasi yang melayani setiap kelompok sosial dengan cara yang sama, dalam hal ini layanan perpustakaan tersebut lebih berfokus pada pelanggan tunggal. Adapun tanggung jawab perpustakaan digital secara lebih luas disampaikan oleh Digital Library Federation (DLF) dimana perpustakaan digital harus mampu memilih, melakukan penyusunan, menawarkan akses, melakukan terjemah, melakukan distribusi, serta pemeliharaan terhadap sumber daya digital sehingga tersedia secara cepat dan ekonomis untuk dapat digunakan oleh suatu komunitas (Digital Library Federation, 2020). Hal ini menandakan bahwa perpustakaan digital memainkan peranan penting terhadap sirkulasi informasi digital sehingga pustakawan mengembangkan suatu mekanisme agar perannya dapat diterima oleh masyarakat.

Sejalan dengan perkembangan teknologi, pada akhirnya perpustakaan digital memanfaatkan teknologi mobile untuk menyampaikan layanannya ke masyarakat yang lebih luas atau dalam hal ini disebut dengan layanan mobile digital library. Secara umum konsep mengenai mobile digital library mengacu pada kombinasi antara jaringan nirkabel dan sistem perpustakaan digital (Ni \& Zhang, 2019). Pengguna mobile digital library dapat membaca dan mengunduh sumber daya digital dari perpustakaan tanpa batasan ruang dan waktu menggunakan gawai mobile (Ni \& Zhang, 2019). Perbedaan antara mobile digital library dengan digital library berada pada media yang digunakan, dalam hal ini mobile digital library menekankan pada penggunaan gawai mobile dalam mengakses perpustakaan digital sedangkan digital library dapat diakses dari gawai digital apapun. Dari konsep tersebut, mobile digital library merupakan bagian dari digital library tetapi lebih difokuskan pada layanan perpustakaan yang diakses melalui gawai mobile sehingga memberikan kemudahan bagi pengguna perpustakaan untuk mengakses layanan informasi dari titik manapun di mana mereka berada.

Gawai mobile memiliki peran tersendiri sebagai dalam membangun ekosistem mobile digital library (Liu et al., 2020). Pertama, mobile digital library memerlukan dukungan teknologi seperti jaringan nirkabel dan teknologi multimedia. Kedua, mobile digital library membutuhkan gawai mobile seperti smartphone. Ketiga, dalam gawai mobile dapat mendukung aktivitas pencarian informasi, penelusuran ataupun pengambilan atau mengunduh dan mengunggah. Adapun dengan bantuan gawai mobile layanan perpustakaan tidak terbatas oleh dimensi ruang dan waktu sehingga bisa diakses dimanapun dan kapanpun, bahkan di daerah terpencil sekalipun, asalkan terdapat jaringan internet (Liu et al., 2020). Melalui pemanfaatan gawai mobile oleh perpustakaan dapat meningkatkan citranya sebagai institusi yang dapat beradaptasi dengan perubahan teknologi sehingga mendorong kelompok usia muda untuk secara alami memanfaatkan layanan perpustakaan digital (Alfaresi \& Hone, 2015). Wang, Li, et al. (2018) mengatakan bahwa penggunaan mobile digital library secara signifikan mampu meningkatkan kepuasan seseorang dalam memenuhi kebutuhan informasi. Berbagai manfaat tersebut sudah seharusnya mobile digital library menjadi pertimbangan untuk dikembangkan oleh perpustakaan sebagai alasan agar layanannya dapat diterima oleh masyarakat secara lebih luas. 


\subsection{Personalized Information Service}

Konseptualisasi mengenai layanan informasi terpersonalisasi (personalized information service) mengacu pada sebuah layanan informasi untuk memenuhi preferensi, kebiasaan, dan karakteristik dari penggunanya (Zhang \& Wang, 2014). Layanan tersebut secara umum dapat diakses melalui jaringan internet (Ghaphery, Kesselman, \& Watstein, 2001). Melalui layanan tersebut suatu institusi harus mampu memberikan pelayanan yang berbeda terhadap setiap pelanggannya, merekomendasikan informasi serta mempertemukan pengguna dengan kebutuhan informasinya (Zhang \& Wang, 2014). Kao \& Wu (2012) menyebutkan bahwa layanan informasi terpersonalisasi mampu mendukung konsep "satu orang, satu perpustakaan" atau "one person, one library".

Salah satu urgensi untuk menerapkan layanan informasi terpersonalisasi adalah kompleksnya informasi yang diberikan oleh perpustakaan, baik perpustakaan digital maupun tradisional, sehingga menimbulkan kebingungan tersendiri pada penggunanya dalam memilih dan menyeleksi informasi sesuai kebutuhannya (Li, Lizhen, \& Yue, 2007). Layanan informasi terpersonalisasi adalah efisiensi dalam mencari, mengorganisir, mengatur, dan mendapatkan tak hanya informasi namun layanan dalam satu titik akses (Ghaphery, Kesselman, \& Watstein, 2001).

Berbagai manfaat dapat diperoleh dari pengimplementasian layanan informasi terpersonalisasi dalam suatu perpustakaan. Taylor \& Corrall (2007) menjelaskan bahwa model personalisasi tidak hanya cocok digunakan dalam konteks lembaga pemerintahan namun harus terus dikembangkan karena mampu mendukung efektivitas dan efisiensi penggunaan informasi serta meningkatkan bidang keahlian dari pegawai lembaga pemerintahan itu sendiri. Melalui layanan informasi terpersonalisasi, fungsi perpustakaan tidak hanya sebagai penyedia informasi saja namun turut mencatat kebutuhan informasi penggunanya, memberikan rekomendasi serta layanan konsultasi mengenai informasi yang relevan terhadap suatu pekerjaan tertentu. Melalui layanan informasi terpersonalisasi, pengguna digital library dapat secara bebas menyusun berkas digital mereka sendiri sesuai dengan keinginan, mengunggah sumber daya pribadi maupun melakukan pengambilan atau memesan sumber daya secara personal (Li, Lizhen, \& Yue, 2007).

Ghaphery, Kesselman, \& Watstein (2001) turut menyampaikan bahwa layanan informasi terpersonalisasi akan memudahkan penggunanya untuk mengingat dimana sumber daya digital favoritnya diletakan di laman perpustakaan. Dalam konteks sosial, layanan informasi terpersonalisasi dinilai mampu menjadi pedoman untuk mengembangkan potensi personal seseorang sehingga mendukung keberagaman sosial (Pang \& Yan, 2012). Berbagai manfaat tersebut pada dasarnya merupakan fungsi utama dari sebuah perpustakaan sebagai pelayan informasi dimana mereka harus mampu memberikan informasi yang dibutuhkan setiap individu (Stojanovski \& Papić, 2012), tetapi dalam skema yang lebih efektif dan efisien (Gambar 1).

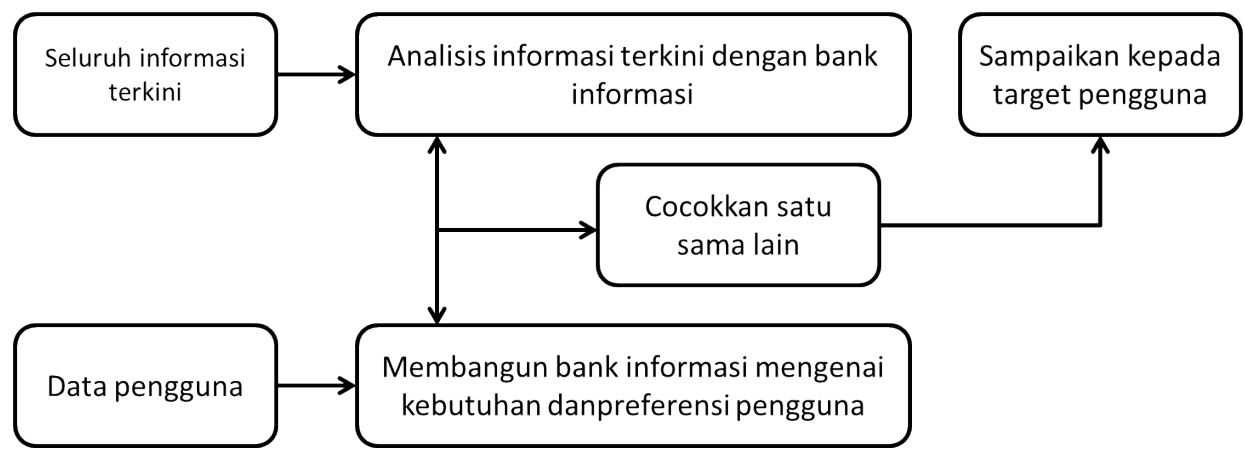

Gambar 1. Alur layanan rekomendasi (Li, Lizhen, \& Yue, 2007) 
Kunci utama untuk melakukan layanan informasi terpersonalisasi terhadap pengguna adalah mengambil informasi dari seorang individu (Zhang \& Wang, 2014). Melalui informasi tersebut suatu layanan perpustakaan dapat memberikan informasi yang akurat terhadap kebutuhan individu dan akhirnya akan memunculkan kepuasan pelayanan (Zhang dan Wang, 2014). Gambar 1 menunjukan bagaimana alur dari salah satu contoh layanan informasi terpersonalisasi yaitu layanan rekomendasi. Gambar 1 menjelaskan bahwa pustakawan harus mampu memadukan kumpulan data pengguna dengan sumber daya informasi terkini sehingga memunculkan rekomendasi untuk pelanggan. Di era revolusi Industri 4.0, seluruh perilaku manusia akan meninggalkan jejak digital pada sistem informasi yang disimpan dalam sistem yang berbeda sehingga perekaman data perilaku pengguna digital library seharusnya dapat dilakukan untuk meningkatkan kualitas pelayanan (Wang, 2016).

Gauch et al. (2007) menjelaskan secara teknis bagaimana memperoleh data pengguna untuk membangun sistem layanan informasi terpersonalisasi. Ada dua cara dalam memperoleh data pengguna yaitu secara eksplisit - data diambil dari sebuah website profil pengguna, dan implisit - data diambil dari perilaku pengguna di internet, misalnya Browse Cache,Web Logs, Search Logs, dsb.

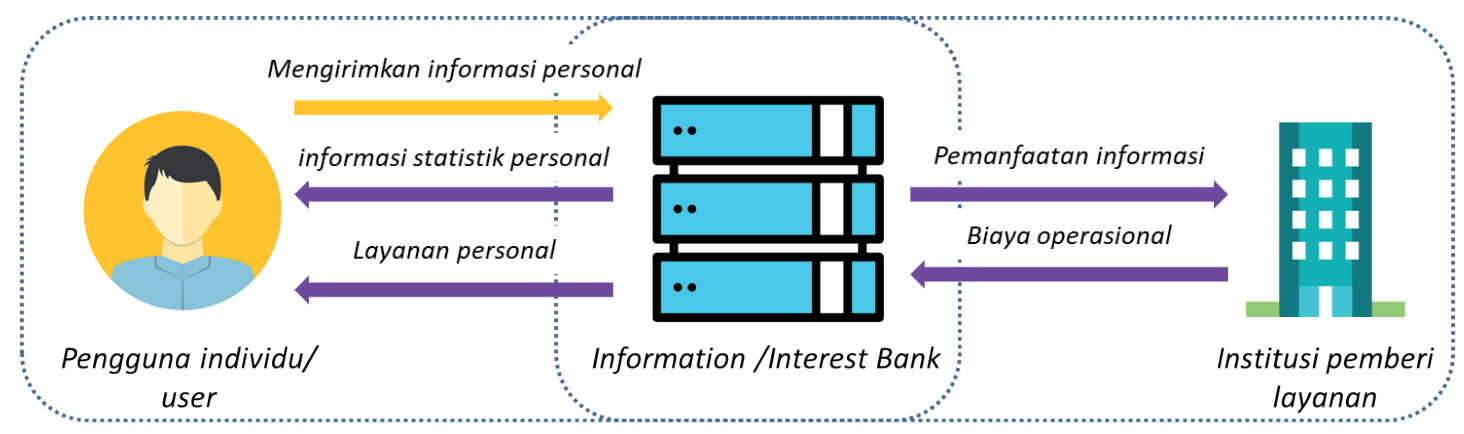

Gambar 2. Model layanan informasi terpersonalisasi (Nakagawa, Matsuda, \& Ogi, 2016)

Peneliti menggunakan model layanan informasi terpersonalisasi dari Nakagawa, Matsuda, \& Ogi (2016). Model tersebut pada dasarnya tidak dalam konteks perpustakaan tetapi model bisnis secara umum. Model tersebut menggambarkan layanan yang terpersonalisasi tidak melalui sudut pandang teknis tetapi lebih ke arah substansi sehingga dapat secara mudah dipahami. Berdasarkan model tersebut, seorang individu akan menggunakan gawai mobile untuk mengakses layanan yang diberikan oleh suatu organisasi. Pelanggan dapat menyampaikan berbagai informasi personalnya kepada organisasi dan menyimpannya di information bank.

Kayaba, Oguri, dan Yamaoka (2020) mengatakan bahwa pengiriman data pribadi ke information bank telah melalui persetujuan dari pengguna layanan sehingga dalam hal ini data tersebut hanya digunakan untuk kepentingan layanan terpersonalisasi dan institusi pemberi layanan memiliki kewajiban untuk tidak menyebarkan data tersebut. Seluruh aktivitas dan perilaku individu dalam menggunakan layanan akan tersimpan di information bank, dalam konteks perpustakaan misalnya buku apa yang dicari, sumber daya apa yang diunduh, berapa lama suatu layanan diakses, dsb. Dari information bank tersebut perusahaan dapat melakukan analisis dari informasi yang disampaikan oleh pengguna dan pengguna dapat mengambil data pribadinya jika diperlukan. Model tersebut dapat dibagi dari aspek pengguna dan perusahaan. Dari aspek pengguna, mereka dapat mengakses layanan dan mengirimkan data pribadi ke information bank. Konsep information bank sama seperti konsep interest bank yang disampaikan oleh Li, Lizhen, \& Yue (2007), di mana interest bank lebih mengarah kepada kumpulan data yang mencakup preferensi pengguna perpustakaan. 


\subsection{Gawai Mobile dan Layanan Terpersonalisasi}

Definisi mengenai gawai mobile mengacu pada sebuah gawai komputer yang berukuran saku dengan ciri-ciri memiliki layar tampilan yang kecil, tombol kecil, atau layar sentuh sebagai input (Dunlop \& Brewster, 2009). Telepon seluler atau telepon mobile merupakan salah satu contoh bentuk dari gawai mobile. Adapun gawai tersebut memiliki kapabilitas untuk berkomunikasi dan tersambung melalui jaringan internet nirkabel. Gawai mobile telah digunakan sebagai asisten pribadi dari setiap individu misalnya dalam mendapatkan pelayanan kesehatan, gawai tersebut telah membantu seseorang untuk melihat rekam medisnya (Dunlop \& Brewster, 2009). Gawai tersebut didesain sedemikian rupa sehingga sisi interaktifnya dapat memberikan pengalaman pribadi yang menyenangkan dari penggunanya.

Personalisasi dalam lingkup teknologi mobile adalah suatu proses yang mengubah fungsi, tampilan antarmuka, akses informasi, dan komunikasi serta keunikan dari suatu sistem untuk meningkatkan relevansi personalnya menjadi kategori individu atau tidak lagi berkategori massal (Asif \& Krogstie, 2013). Argumen tersebut menunjukan bahwa ada unsur perekayasaan teknologi yang sedemikian rupa sehingga teknologi mobile menjadi alat untuk memenuhi kebutuhan personal seorang pelanggan. Pengguna akan membangun ruang privasi tersendiri dengan gawai mobile yang mereka miliki. Teknologi mobile akan menguatkan karakteristik dan keunikan dari seseorang sehingga hal ini akan menjadi dorongan dalam membangun ekosistem layanan terpersonalisasi. Ekosistem tersebut pada akhirnya terbentuk dengan sendirinya karena bagaimanapun juga penyedia layanan harus mencari cara untuk memenuhi kebutuhan dan memberikan kepuasan layanan bagi pelanggannya. Zhang \& Wang (2014) yang menyampaikan bahwa layanan terpersonalisasi sendiri merupakan cara perpustakaan dalam menarik calon pengguna untuk berpartisipasi dalam layanannya.

Beberapa penelitian menyebutkan bahwa gawai mobile merupakan alat yang cocok untuk memenuhi layanan yang terpersonalisasi. Wang (2011) menyampaikan bahwa saat ini penggunaan gawai mobile telah mampu memenuhi kebutuhan yang berpusat pada manusia, membangun privasi dan membangun karakter secara alami sehingga nantinya akan banyak permintaan untuk mengembangkan gawai tersebut untuk memenuhi kebutuhan pribadi secara personal. Gawai mobile telah mampu mendukung aplikasi yang mendukung layanan personalisasi. Wei \& Yang (2017) mengatakan bahwa aplikasi mobile WeChat telah mampu menyediakan layanan langganan pribadi terkait sumber daya digital pada suatu universitas di Tiongkok. Aplikasi yang tersedia di gawai mobile menjadi suatu alat yang mendukung interaktivitas antara pengguna dan pemberi layanan sehingga pemberi layanan dapat mengetahui secara pasti kebutuhan dari pengguna (Wang, Yang, et al., 2018). Gawai mobile mempermudah pemberi layanan untuk memperoleh data mengenai penggunanya sehingga dapat memahami kebutuhan pengguna (Nakagawa, Matsuda, \& Ogi, 2016).

\section{METODE}

Artikel penelitian ini berjenis penelitian konseptual yang menggunakan metode tinjauan literatur. Penelitian konseptual mengacu pada suatu peninjauan dengan tujuan untuk melakukan sintesis lingkup dari pengetahuan konseptual sehingga dapat memberikan pemahaman mengenai isu yang diteliti (Petticrew \& Roberts, 2008). Metode tinjauan literatur merupakan teknik yang memiliki berbagai macam tujuan (Ridley, 2012). Metode tersebut digunakan untuk mengintegrasikan dan merangkum apa yang telah diketahui dalam suatu lingkup sehingga terkumpul berbagai pengetahuan yang dapat mengarahkan kepada penelitian lainnya (Neuman, 2008). Adapun pendekatan yang digunakan dalam penelitian ini adalah deskriptif - kualitatif, karena tujuan utama penelitian ini adalah untuk memberikan sebuah gambaran menggunakan kata-kata atau angka untuk menggambarkan suatu isu yang dibahas (Neuman, 2008). Penelitian ini menggambarkan peran dari gawai mobile dalam mendukung layanan perpustakaan digital yang terpersonalisasi melalui penelusuran literatur yang memiliki relevansi isu. Dalam melakukan metode tinjauan literatur yang baik maka diperlukan 
sebuah perencanaan dalam mencari literatur dan menulis hasilnya sehingga tujuan penelitian akan disampaikan secara konsisten (Neuman, 2008). Penelitian ini menggunakan prosedur tinjauan literatur yang diajukan oleh Cronin, Ryan, \& Coughlan (2008), sebagaimana yang terlihat pada Tabel 1.

Tabel 1. Prosedur Penelitian

\begin{tabular}{|c|c|c|}
\hline No. & Fase & Uraian Prosedur \\
\hline 1 & $\begin{array}{l}\text { Menentukan topik peneli- } \\
\text { tian yang akan ditinjau }\end{array}$ & $\begin{array}{l}\text { Fase pertama ini merupakan tahap untuk merancang serta menentukan } \\
\text { pertanyaan yang akan dijawab melalui tinjauan literatur: } \\
\text { Apa saja peran yang dapat dimunculkan oleh gawai mobile dalam } \\
\text { mendukung perpustakaan digital sebagai layanan informasi yang } \\
\text { terpersonalisasi? }\end{array}$ \\
\hline 2 & $\begin{array}{l}\text { Melakukan pencarian lit- } \\
\text { eratur secara prosedural }\end{array}$ & $\begin{array}{l}\text { Fase kedua ini merupakan tahap untuk melakukan identifikasi terhadap } \\
\text { literatur yang memiliki relevansi sesuai dengan topik penelitian. } \\
\text { - Mengidentifikasi dan menentukan kata kunci penelusuran literatur } \\
\text { (mobile device, digital library, mobile digital library, personaliza- } \\
\text { tion, personalized, dan information service). } \\
\text { Menentukan basis data literatur ilmiah yang akan digunakan seb- } \\
\text { agai dasar penulisan (Scopus dan Google Scholar). }\end{array}$ \\
\hline 3 & $\begin{array}{l}\text { Mengumpulkan, mem- } \\
\text { baca, dan menganalisis isi } \\
\text { literatur }\end{array}$ & $\begin{array}{l}\text { Fase ketiga ini merupakan tahapan untuk mengklasifikasikan hasil pen- } \\
\text { elusuran menjadi sumber primer dan sumber sekunder. Sumber primer } \\
\text { adalah berbagai literatur ilmiah, empiris maupun konseptual, yang } \\
\text { relevan dengan topik utama. Sumber sekunder adalah literatur ilmiah } \\
\text { yang meninjau topik lain namun mencakup beberapa konsep atau topik } \\
\text { yang dibahas dalam penelitian ini. } \\
\text { Dalam penelitian ini turut diimplementasikan kriteria inklusi dan } \\
\text { eksklusi sebagai dasar seleksi literatur. } \\
\text { - Kriteria inklusi. Literatur yang akan diterima pada hasil penelu- } \\
\text { suran adalah penelitian empiris maupun konseptual yang menjelas- } \\
\text { kan penggunaan maupun menyinggung peran gawai mobile } \\
\text { sebagai akses pengguna pada perpustakaan digital yang layanannya } \\
\text { terpersonalisasi. } \\
\text { Kriteria eksklusi. Literatur yang ditolak dalam hasil penelusuran } \\
\text { adalah penelitian yang tidak memunculkan gawai mobile sebagai } \\
\text { media dalam mengakses perpustakaan digital. }\end{array}$ \\
\hline 4 & $\begin{array}{l}\text { Menuliskan hasil analisis } \\
\text { dalam sebuah laporan }\end{array}$ & $\begin{array}{l}\text { Fase terakhir merupakan tahapan ketika penulis menyampaikan hasil } \\
\text { analisis berdasarkan data penelitian yang telah diperoleh. Untuk men- } \\
\text { jaga konsistensi, penulis membahasnya melalui komponen-komponen } \\
\text { dari model perpustakaan digital yang sebelumnya telah disampaikan } \\
\text { dalam tinjauan literatur. Adapun fase ini akan disampaikan pada bagian } \\
\text { hasil dan pembahasan. }\end{array}$ \\
\hline
\end{tabular}

Sumber: Cronin, Ryan, \& Coughlan (2008)

Berdasarkan hasil penelusuran literatur sesuai dengan prosedur penelitian, diperoleh 7 literatur yang menjadi data utama penelitian ini (Tabel 2). Tujuh literatur tersebut akan dianalisis untuk mendapatkan informasi yang sesuai dengan topik penelitian.

Tabel 2. Daftar Literatur Penelitian

\begin{tabular}{cll}
\hline No. & Penulis(tahun) & Uraian Singkat Penelitian \\
\hline 1 & Noh (2015) & Noh menjelaskan konsep Library 4.0 sebagai model masa depan \\
& & perpustakaan digital, dan layanan terpersonalisasi menjadi salah satu \\
& & karakteristik pada konsep perpustakaan tersebut. \\
\hline
\end{tabular}




\begin{tabular}{|c|c|c|}
\hline No. & Penulis(tahun) & Uraian Singkat Penelitian \\
\hline 2 & Wang et al. (2018) & $\begin{array}{l}\text { Penelitian ini bertujuan untuk menganalisis faktor-faktor yang mem- } \\
\text { pengaruhi perilaku pengguna dalam menggunakan mobile digital } \\
\text { library dalam perspektif ekologi informasi. }\end{array}$ \\
\hline 3 & Li et al. (2019) & $\begin{array}{l}\text { Penelitian ini memberikan gambaran mengenai pengaplikasian } \\
\text { teknologi informasi terkini dalam konteks perpustakaan digital. }\end{array}$ \\
\hline 4 & Wei \& Yang (2017) & $\begin{array}{l}\text { Penelitian ini menganalisis suatu aplikasi mobile digital library yang } \\
\text { bernama WeChat Library sebagai media sosial yang telah digunakan } \\
\text { oleh salah satu universitas untuk mengakses layanan perpustakan }\end{array}$ \\
\hline 5 & Zhao et al. (2016) & $\begin{array}{l}\text { Penelitian ini bertujuan untuk menggali dampak dari pengalaman } \\
\text { pengguna terhadap kebutuhan pengguna dari dua buah kelompok } \\
\text { penelitian. }\end{array}$ \\
\hline 6 & Sharman (2014) & $\begin{array}{l}\text { Penelitian ini menganalisis bagaimana gawai mobile dapat membantu } \\
\text { proyek Roving Librarian untuk membantu pengguna yang tidak ter- } \\
\text { daftar di perpustakaan dalam lingkup sosial dan akademik. }\end{array}$ \\
\hline 7 & Singh \& Nikandia (2017) & $\begin{array}{l}\text { Penelitian konseptual ini menggambarkan bagaimana aplikasi teknolo- } \\
\text { gi mobile dalam menunjang layanan perpustakaan. }\end{array}$ \\
\hline
\end{tabular}

Sumber: olahan peneliti (2021)

\section{HASIL DAN PEMBAHASAN}

Berdasarkan model layanan informasi terpersonalisasi yang telah disampaikan dalam tinjauan literatur, setidaknya terdapat dua aspek yang dapat dibahas dalam mekanisme layanan informasi terpersonalisasi melalui gawai mobile yaitu aspek pengumpulan data dan aspek layanan perpustakaan yang diberikan.

Pengumpulan data merupakan proses penting dalam mekanisme ini karena data dari pengguna akan disimpan pada information bank - menjadi sumber daya perpustakaan dalam membangun rekomendasi sesuai dengan preferensi dan data dari penggunanya. Adapun aspek layanan perpustakaan merupakan aspek yang menjelaskan mengenai apa saja layanan yang dapat disampaikan oleh gawai mobile dibandingkan dengan layanan yang tidak mobile. Aspek ini perlu dibahas karena teknologi tersebut memberikan efektivitas dan efisiensi pada setiap layanan yang disampaikan oleh perpustakaan. Gawai mobile mampu menghadirkan personalisasi terhadap layanan yang diberikan secara mobile sehingga hal ini menjadi dasar untuk melihat seberapa jauh personalisasi layanan tersebut telah dilakukan. Penelitian ini tidak berfokus pada dampak negatif dari pemanfaatan data pengguna meskipun pada nyatanya privasi dan keamanan data pengguna merupakan salah satu hal yang menjadi konsekuensi dalam penggunaan gawai mobile (Wang, 2011).

\subsection{Aspek Pengumpulan Data}

Penggunaan gawai mobile dalam membangun layanan mobile digital library yang terpersonalisasi dapat memberikan kemudahan bagi perpustakaan dalam mengumpulkan informasi dari pengguna melalui fasilitas yang tersedia. Singh \& Nikandia (2017) menyampaikan bahwa dalam memberikan pelayanan yang berpusat pada penggunanya, suatu perpustakaan dapat menggunakan survei melalui e-mail maupun short message service. Survei melalui gawai mobile tersebut digunakan untuk memperoleh feedback dari penggunanya sehingga perpustakaan dapat memberikan layanan informasi yang terspesialisasi dan terpersonalisasi. Aplikasi mobile yang dikembangkan oleh suatu perpustakaan dapat menjadi media bagi perpustakaan dan penggunanya untuk saling berkolaborasi dalam penyediaan layanan terpersonalisasi (Zhao et al., 2016). Bahkan dalam mendapatkan informasi dari pengguna layanan perpustakaan, sambungan telepon turut dijadikan sebagai media komunikasi (Zhao et al., 2016). Sebagai salah satu gawai yang dapat mendukung fasilitas world wide web, 
gawai mobile dapat membentuk data mengenai jejak pencarian yang dilakukan (Gauch et al., 2007). Data tersebut digunakan sebagai dasar untuk mengidentifikasi preferensi produk atau layanan dari penggunanya (Gauch et al., 2007).

Kemudahan yang diberikan oleh gawai mobile dalam mendukung pengumpulan data pengguna dapat dilihat dari beberapa sisi, salah satunya sisi sosial. Wang (2011) menyampaikan bahwa gawai mobile telah menjadi ruang personal dari seorang pelanggan sehingga hal tersebut menjadikan gawai mobile menjadi sebuah sumber yang menyediakan data pribadi untuk dimaksimalkan oleh perpustakaan digital. Gawai mobile sendiri mendukung interaktivitas atau komunikasi dua arah dari pengguna dengan pengelola perpustakaan sehingga fasilitas ini menjadi pendukung dalam penyampaian feedback dari pengguna (Wang, Yang, et al., 2018). Dalam fenomena roving librarian yang disampaikan oleh Sharman (2014), gawai mobile telah menjadi alat untuk mendampingi setiap aktivitas pengguna perpustakaan digital sehingga pengguna dapat menghubungi pustakawan kapanpun meskipun saat sedang bekerja. Hal tersebut menandakan bahwa pustakawan harus mampu memaksimalkan dan terus mencari peluang agar mereka mampu mendapatkan data pengguna sebagai dasar dalam memberikan pelayanan yang sesuai dengan kebutuhan.

Teknologi yang hadir pada revolusi industri 4.0 turut memberikan kemudahan bagi perpustakaan digital untuk mendapatkan data atau masukan dari pelanggan. Pada beberapa perpustakaan di Tiongkok, kecerdasan buatan telah memungkinkan suatu perpustakaan menggunakan sebuah robot yang dapat mengenali suara dari manusia (Li et al., 2019). Tidak hanya mendengar dan mengenali bahasa manusia, robot dengan kecerdasan buatan tersebut dapat berkomunikasi dengan manusia dalam memberikan referensi bacaan yang mereka butuhkan. Internet of Things menjadi salah satu teknologi yang telah memberikan berbagai macam manfaat pada perpustakaan (Mohammadi \& Yegane, 2018).

Salah satu manfaat penggunaan IoT dalam konteks perpustakaan digital mobile adalah memberikan informasi mengenai lokasi geografis dari pengguna perpustakaan sehingga pengguna dapat memperoleh petunjuk arah mengenai sumber daya yang dibutuhkan (Mohammadi \& Yegane, 2018). Berbagai kemudahan tersebut menunjukan bahwa perpustakaan harus mulai sadar dengan perkembangan teknologi saat ini agar di masa depan institusi tersebut dapat memberikan layanan untuk memenuhi kebutuhan personal dari masing-masing individu secara efisien.

Otomatisasi menjadi salah satu aspek yang tidak dapat dipisahkan dari pemanfaatan teknologi yang lahir pada revolusi industri 4.0 dalam proses pengambilan data. Melalui teknologi Web 3.0, mesin pencari akan menganalisis setiap data pengguna menjadi data yang lebih mikro secara otomatis sehingga dapat menghasilkan suatu rekomendasi pencarian yang lebih baik (Noh, 2015). Analisis data mikro tersebut dapat memahami sinonim maupun homonim dari kata kunci yang digunakan saat mencari suatu informasi. Tidak hanya data dari pengguna, melalui kecerdasan buatan, suatu perpustakaan dapat mengambil data berukuran besar dari berbagai basis data dan melakukan Big Data Mining secara otomatis untuk membangun struktur berpikir suatu mesin dengan kemampuan seperti manusia (Li et al. 2019; Noh, 2015).

Noh (2015) menyampaikan bahwa kecerdasan buatan yang menjadi ciri khas teknologi revolusi industri 4.0 akan membuat keputusan berdasarkan bagaimana cara kita hidup dan apa yang kita butuhkan secara otomatis. Hal ini menunjukan bahwa di masa depan, pengembangan layanan perpustakaan diprediksi akan mengarah ke sifat mobile, terotomatisasi, efektif, dan efisien. Dilihat dari sisi teknis, saat ini gawai mobile telah dilengkapi oleh berbagai fasilitas untuk mendapatkan berbagai macam data dari penggunanya (Khaddar \& Boulmalf, 2017). Gawai tersebut dapat memperoleh data lokasi geografis, temperatur lingkungan, kondisi kesehatan dari penggunanya serta dapat melakukan komunikasi tidak hanya dengan manusia tetapi dengan mesin yang lainnya baik melalui Near Field Communication (NFC), jaringan Wi-Fi, dsb. (Khaddar \& Boulmalf, 2017). 
Kamilaris \& Pitsillides (2016) menyampaikan bahwa gawai mobile saat ini telah menjadi gawai multi-sensor yang tersambung dengan internet sehingga dapat diperoleh berbagai data mengenai setiap aktivitas seperti jarak, kecepatan, lokasi, suara, ataupun tangkapan gambar. Gawai mobile telah menjadi alat yang mampu menghasilkan berbagai jenis data dengan jumlah yang besar. Kondisi ini dinilai menjadi suatu pendukung terhadap pelayanan informasi yang terpersonalisasi karena layanan tersebut dirancang berdasarkan analisis data atau data-driven service.

\subsection{Aspek Layanan}

Dalam penyampaian layanan informasi terpersonalisasi, gawai mobile dapat berperan untuk mendukung kerja aplikasi mobile sehingga akses menuju perpustakaan digital lebih mudah dilakukan oleh pengguna. Sharman (2014) menyampaikan bahwa melalui gawai mobile, pengguna perpustakaan dapat mengunduh berbagai macam aplikasi yang dapat mendukung mereka dalam mengkonsumsi informasi dari digital library. Bahkan ada media sosial yang dikhususkan sebagai saluran komunikasi untuk para penggunanya, misalnya Seesmic Ping (Sharman, 2014). Penggunaan aplikasi mobile dibutuhkan oleh beberapa pengguna perpustakaan karena dinilai merupakan pendekatan terbaik dalam mempermudah akses (Zhao et al., 2016).

Wei \& Yang (2017) menjelaskan bahwa aplikasi mobile WeChat telah menjadi media untuk mengakses perpustakaan universitas di Tiongkok. Survei deskriptif dari Mansouri \& Soleymani-Asl (2019) mengenai penggunaan aplikasi perpustakaan mobile menyampaikan bahwa aplikasi tersebut dapat memenuhi kebutuhan dasar pengguna perpustakaan digital dalam hal layanan sirkulasi dan peminjaman.

Fenomena penggunaan aplikasi mobile dalam sebuah gawai memberikan implikasi bahwa saat ini sudah ada beberapa perpustakaan yang mampu memaksimalkan peluang dalam memberikan layanan yang lebih personal dan efisien kepada pengguna. Wang (2011) menyampaikan bahwa perpustakaan akan mengembangkan aplikasi mobile dengan tujuan memenuhi kebutuhan pribadi. Perpustakaan digital sebisa mungkin dapat mengembangkan aplikasi mobile sehingga dapat memberikan layanan informasi dengan cara yang lebih modern dan mengikuti perkembangan zaman. Alfaresi \& Hone (2015) menyampaikan bahwa penerimaan mobile digital library pada kelompok usia muda di Uni Emirat Arab turut didukung oleh penggunaan teknologi mobile yang memberikan citra kekinian terhadap institusi perpustakaan. Sharman (2014) memberikan contoh yang cukup baik, di mana manusia sebagai pelayan informasi turut menggunakan aplikasi mobile dalam mendukung program roving librarian sehingga dapat memunculkan model layanan perpustakaan baru dalam memberikan layanan informasi terpersonalisasi kepada penggunanya.

Gawai mobile dinilai mampu untuk mengakses berbagai macam layanan secara efektif dan efisien yang sebelumnya tidak dapat dilakukan pada perpustakaan tradisional. Aplikasi WeChat dinilai mampu mendukung berbagai proses diseminasi informasi perpustakaan melalui tingkat interaktivitas yang tinggi, konsultasi secara real-time, promosi yang lebih mudah dan lain sebagainya (Wei \& Yang, 2017). Adapun melalui aplikasi WeChat, seseorang dapat melakukan reservasi tempat duduk yang akan digunakan pada perpustakaan fisik. Dari perspektif pustakawan, penyampaian informasi mengenai batas peminjaman buku melalui media sosial dapat disampaikan secara mudah dan murah (Wei \& Yang, 2017).

Kubat (2017) menjelaskan bahwa gawai mobile telah mampu menyampaikan informasi melalui katalog digital, layanan short messaging service/SMS, konsultasi melalui chat room, aplikasi pembaca kode QR bahkan menggunakan fasilitas augmented reality/AR. Mansouri \& Soleymani (2019) menyampaikan bahwa fasilitas bertanya kepada pustakawan (ask a librarian) adalah salah satu fasilitas yang sering diakses oleh pengguna melalui gawai mobile. Adapun bertanya kepada pustakawan merupakan fasilitas komunikasi melalui chat maupun email sehingga pengguna dapat memperoleh informasi sesuai dengan kebutuhan. 
Digitalisasi layanan dari perpustakaan membuka gagasan bahwa penggunaan gawai mobile dalam mengakses perpustakaan digital diharapkan mampu memberikan kesamaan pengalaman ketika berkunjung ke perpustakaan fisik. Wei \& Yang (2017) menyampaikan bahwa kegiatan konsultasi dengan pustakawan dapat digantikan dengan layanan berbasis digital, begitu juga dengan aktivitas peminjaman buku dapat dilakukan secara virtual. Adapun yang membedakan proses online dengan proses offline tersebut adalah bahwa pengguna dapat mengakses layanan kapanpun dan dimanapun berada sehingga dapat disesuaikan dengan keadaan, situasi dan kebutuhan dari penggunanya. Hal ini merupakan solusi dari permasalahan utama yang diangkat dalam penelitian ini dimana saat ini banyak informasi yang tersebar di internet sehingga sebisa mungkin layanan perpustakaan dapat memberikan layanan informasi dimanapun dan bagaimanapun keadaan pengguna.

Gawai mobile yang dikembangkan saat ini telah menjadi alat yang berteknologi tinggi sehingga dapat mendukung kerja program-program teknologi yang lahir pada revolusi industri 4.0. Noh (2015) menyampaikan bahwa gawai mobile merupakan karakteristik utama dari konsep Library 3.0 yang didukung oleh teknologi Semantic Web. Ciri layanan dari konsep perpustakaan tersebut adalah terpersonalisasi dan terkostumisasi, dalam hal ini suatu mesin bekerja dengan menerapkan kecerdasan buatan/artificial intelligence untuk terus belajar memenuhi kebutuhan penggunanya. Mohammadi \& Yegane (2018) menjelaskan bahwa teknologi sensor Radio Frequency Identification (RFID) dapat dimanfaatkan untuk memindai buku yang telah datang sehingga pelanggan dapat langsung menerima pemberitahuan mengenai buku yang sudah dipesan.

Li et al. (2019) menyampaikan bahwa teknologi kecerdasan buatan telah dimanfaatkan pada berbagai mobile digital library di Tiongkok untuk menjadi smart library, di mana perpustakaan tersebut mampu memberikan layanan interaktif yang terpersonalisasi berdasarkan lokasi penggunanya berada. Terdapat tiga manfaat yang dapat dikembangkan mobile digital library melalui kecerdasan buatan yaitu meningkatkan layanan tradisional dari perpustakaan terutama pada aspek sirkulasi buku, manajemen pembaca dan manajemen dokumen, meningkatkan kemampuan perpustakaan digital untuk menyediakan layanan pengetahuan yang baru, di mana konten didorong oleh data dan subjek ilmu semakin beragam, serta menguatkan manajemen dari perpustakaan itu sendiri (Li et al., 2019). Teknologi Internet of Things (IoT) juga telah digunakan oleh berbagai perpustakaan untuk mentransformasikan dirinya menjadi perpustakaan digital sehingga dapat menyediakan berbagai layanan, dan salah satunya memberikan efisiensi dalam pencarian sumber daya digital (Wang, $\mathrm{Li}$, et al., 2018).

Pengembangan mobile digital library melalui teknologi revolusi industri 4.0, sangat memungkinkan perpustakaan di masa depan dapat berkembang menjadi lebih personal dari saat ini. Berbagai pemanfaatan kecerdasan buatan mengarahkan pada satu gagasan dimana perpustakaan akan terus mempelajari perilaku, karakteristik dan keadaan dari penggunanya atau dalam hal ini suatu mesin komputer akan memiliki peran sebagai pustakawan. Noh (2015) memberikan sebuah skenario masa depan perpustakaan dalam konsep library 4.0 di mana suatu perpustakaan digital akan menjadi perpustakaan yang pintar dimana suatu sistem tidak hanya memberikan layanan informasi tapi turut aktif berdiskusi dengan penggunanya sama seperti kolega. Perpustakaan harus mampu melihat permasalahan dan keadaan manusia yang semakin heterogen sehingga personalisasi layanan menjadi hal yang memiliki urgensi tinggi di masa depan.

Tidak hanya dari sisi teknologi, gawai mobile telah mampu memberikan manfaat dari sisi sosial. Kubat (2017) menjelaskan bahwa gawai mobile akan membangun bentuk keterlibatan baru dari penggunanya untuk belajar sehingga melalui gawai tersebut pustakawan harus mampu membangun hubungan baik dalam pendampingan proses belajar penggunanya. Pada konteks media sosial, penggunaan WeChat sebagai akses perpustakaan perusahaan dapat mempermudah proses berbagi informasi kepada pengguna lainnya. Di Tiongkok, aplikasi WeChat tersebut menjadi salah satu media sosial yang paling banyak digunakan (Wei \& Yang, 2017). 
Sharman (2014) mengenai penggunaan gawai Android dan iPad pada Roving Librarian, Sharman menyampaikan bahwa kedua perangkat tersebut memungkinkan pustakawan untuk memberikan bantuan yang terpersonalisasi kepada penggunanya sambil membangun hubungan yang lebih kuat, dan layanan tersebut tidak akan terjadi jika pustakawan hanya berdiam diri di perpustakaan fisik. Beberapa manfaat sosial tersebut secara tidak langsung menunjukan bahwa pada akhirnya gawai mobile mendukung layanan yang berfokus pada pengguna (user centric).

Layanan informasi yang terpersonalisasi pada dasarnya sudah memiliki substansi sosial karena layanan tersebut memiliki konsep yang berfokus kepada manusia (human centric). Sharman (2014) menyampaikan bahwa dengan mengimplementasikan layanan tersebut pada suatu perpustakaan maka institusi tersebut dinilai memiliki kepekaan terhadap masalah sosial. Gawai mobile tidak hanya berfokus pada masalah sosial penggunanya saja namun turut membantu pekerjaan pustakawan. Selain itu, dampak sosial yang dapat didukung oleh gawai mobile sesuai dengan konsep pengembangan berkelanjutan (Li, Lizhen, \& Yue, 2007). Salah satu aspek dari pembangunan berkelanjutan adalah keberlanjutan sosial dimana hal ini menekankan pada layanan yang inklusif atau persamaan akses dari masyarakat (Mishaal \& Abu-shanab, 2015). Layanan mobile digital library mampu diakses oleh penggunanya pada daerah terpencil/remote area sekalipun (Liu et al., 2020).

\section{KESIMPULAN}

Gawai mobile memiliki peran yang cukup penting pada aspek pengumpulan data dan pelayanannya. Dalam aspek pengumpulan data, gawai mobile telah menjadi asisten pribadi yang memiliki peran sebagai media untuk menghadirkan efektivitas dan efisiensi dalam berkomunikasi dengan penyedia layanan perpustakaan. Adapun berbagai jenis teknologi revolusi industri 4.0 dapat diaplikasikan pada gawai mobile sehingga alat tersebut akan secara otomatis bekerja dengan perpustakaan dalam memberikan layanan yang personal. Pengumpulan data dari pelanggan tidak hanya berasal dari data teks saja, namun saat ini telah digunakan kecerdasan buatan sehingga suatu robot telah mampu mengenali dan mempelajari bahasa manusia. Dalam aspek pelayanan, aplikasi mobile telah memungkinkan pengguna perpustakaan untuk melakukan berbagai hal yang berkaitan dengan kepustakaan secara online dengan efektif dan efisien. Bahkan dengan kecanggihan tersebut gawai mobile turut memberikan dampak sosial tersendiri baik kepada pengguna maupun pustakawan. Beberapa skenario perpustakaan di masa depan turut menyampaikan bahwa penggunaan teknologi revolusi industri 4.0 akan memberikan berbagai manfaat, bahkan otomatisasi pada layanan informasi perpustakaan yang lebih personal kepada penggunanya. Pada akhirnya terdapat suatu urgensi tersendiri untuk memanfaatkan gawai mobile untuk mengatasi masalah ledakan informasi sehingga masyarakat memiliki informasi sebagai panduan informasi yang terpercaya untuk digunakan dalam setiap aktivitasnya.

Terdapat beberapa keterbatasan pada artikel ini. Pertama, penelitian ini tidak membahas secara luas bagaimana dampak negatif dari layanan terpersonalisasi ini padahal risiko keamanan dan privasi data menjadi salah satu dampak yang dapat memberikan dampak negatif pada pengguna. Kedua, penelitian ini hanya menggunakan metodologi penelitian tinjauan literatur, sehingga tidak dapat dilakukan triangulasi terhadap temuan penelitian. Ketiga, penelitian ini tidak menjelaskan hal-hal teknis baik dalam aspek pengumpulan data maupun akses layanan padahal pemahaman teknis mengenai teknologi tersebut perlu dituangkan untuk memberikan gambaran mengenai mekanisme yang telah digunakan oleh beberapa perpustakaan. Penelitian ini diharapkan dapat menjadi pijakan bagi peneliti selanjutnya dalam mengamati dan memahami fenomena penggunaan gawai mobile dan layanan informasi terpersonalisasi. Kesiapan dari institusi perpustakaan, terutama di Indonesia, dalam mengimplementasikan layanan dalam bentuk mobile dapat menjadi kajian yang dapat memperkaya pemahaman ekosistem perpustakaan mobile digital. Penelitian selanjutnya dapat menggambarkan dan menganalisis berbagai skema maupun mekanisme mobile digital library yang menyampaikan layanan informasi terpersonalisasi secara empiris, terutama di Indonesia. 


\section{DAFTAR PUSTAKA}

Alfaresi, S.H., \& Hone, K. 2015. The Intention to Use Mobile Digital Library Technology: A Focus Group Study in the United Arab Emirates. International Journal of Mobile Human Computer Interaction, 7(2): 23-42. https://doi.org/10.4018/ijmhci.2015040102.

Asif, M., \& Krogstie, J. 2012. Research Issues in Personalization of Mobile Services. International Journal of Information Engineering and Electronic Business, 4(4): 1-8. https://doi.org/10.5815/ ijieeb.2012.04.01. Asif, M., \& Krogstie, J.

Asif, M., \& Krogstie, J. 2013. Role of Personalization in Mobile Services Adoption. International Conference on Multimedia and Human Computer Interaction, 59: 1-10.

Bal, H.C., \& Erkan, C. 2019. Industry 4.0 and Regional Transformations. Procedia Computer Science 158: 625-31. https://doi.org/10.1016/j.procs.2019.09.096.

Buarki, H.J., \& Ahmad-Dar, S. 2019. Anytime, Anywhere Access to Information Resources: A Case Study from Kuwait. Library Hi Tech News, 36(7): 20-24. https://doi.org/10.1108/LHTN-08-2019-0049.

Cronin, P., Ryan, F., \& Coughlan, M. 2008. Undertaking a Literature Review: A Step-by-Step Approach. British Journal of Nursing, 17(1): 38-43. https://doi.org/10.12968/bjon.2008.17.1.28059.

Digital-Library-Federation. D. 2020. A Working Definition of Digital Library. https://old.diglib.org/about/ dldefinition.htm\#: :text=\%22Digital libraries are organizations that,are readily and economically available.

Dunlop, M., \& Brewster, S. 2009. The Challenge of Mobile Devices for Human Computer Interaction. Personal and Ubiquitous Computing, 6(4): 235-36. https://doi.org/10.1007/s007790200022.

Gauch, S., Speretta, M., Chandramouli, A., \& Micarelli, A. 2007. User Profiles for Personalized Information Access. Lecture Notes in Computer Science (Including Subseries Lecture Notes in Artificial Intelligence and Lecture Notes in Bioinformatics) 4321 LNCS: 54-89. https://doi.org/10.1007/9783-540-72079-9_2.

Gbotosho, A.S. 2019. The Electronic Library Services and Its Patronage Among Undergraduates In The Faculty Of Health Sciences, Osun State University, Osogbo, Osun State, Nigeria. International Journal of Library and Information Science Studies, 5(1): 41-54.

Ghaphery, J., Kesselman, M., \& Watstein, S.B. 2001. Personalized Information Clients: Short Answers to Simple Questions about 'My Library' Services. Reference Services Review, 29 (4): 276-81. https://doi.org/10.1108/EUM0000000006489.

Houhamdi, Z., \& Athamena, B. 2019. Impacts of Information Quality on Decision-Making. Global Business and Economics Review, 21(1): 26. https://doi.org/10.1504/gber.2019.10017577.

Jeevan, V.K.J., \& Padhi, P. 2006. “A Selective Review of Research in Content Personalization.” Library Review, 55(9): 556-86. https://doi.org/10.1108/00242530610706761.

Kamilaris, A., \& Pitsillides, A. 2016. Mobile Phone Computing and the Internet of Things: A Survey. IEEE Internet of Things Journal, 3(6): 885-98. https://doi.org/10.1109/JIOT.2016.2600569.

Kao, S.C., \& Hsing-Wu, C. 2012. PIKIP DL A Personalized Information and Knowledge Integration Platform for DL Service. Library Hi Tech, 30(3): 490-512. https://doi.org/10.1108/07378831211266627.

Kayaba, K., Oguri, H., \& Yamaoka, Y. 2020. Evaluation of Secure Remote Offering Service for Information Bank. CODASPY 2020 - Proceedings of the 10th ACM Conference on Data and Application Security and Privacy, 144-46. https://doi.org/10.1145/3374664.3379526.

Khaddar, M.A.E., \& Boulmalf, M. 2017. Smartphone: The Ultimate IoT and IoE Device. Smartphones from an Applied Research Perspective. https://doi.org/10.5772/intechopen.69734.

Kubat, G. 2017. The Mobile Future of University Libraries and an Analysis of the Turkish Case. Information and Learning Science, 118(3-4): 1-23. https://doi.org/10.1108/ILS-09-2016-0063.

Li, Q., Lizhen, L., \& Yue, H. 2007. Analysis of Personalized Information Service System for Digital Libraries. Proceedings of the 2007 1st International Symposium on Information Technologies and Applications in Education, ISITAE 2007, 233-37. https://doi.org/10.1109/ISITAE.2007.4409277. 
Li, S., Hao, Z., Ding, L., \& Xu, X. 2019. Research on the Application of Information Technology of Big Data in Chinese Digital Library. Library Management, 40(8-9): 518-31. https://doi.org/10.1108/ LM-04-2019-0021.

Liu, L., Su, X., Akram, U., \& Abrar, M. 2020. The User Acceptance Behavior to Mobile Digital Libraries. International Journal of Enterprise Information Systems, 16(2): 38-53. https://doi.org/10.4018/ IJEIS.2020040103.

Mansouri, A., \& Soleymani, N.A. 2019. Assessing Mobile Application Components in Providing Library Services. Electronic Library, 37(1): 49-66. https://doi.org/10.1108/EL-10-2018-0204.

Mishaal, D.A., \& Abu-shanab, E. 2015. The Effect of Using Social Media in Governments: Framework of Communication Success, 357-64. https://doi.org/10.15849/icit.2015.0069.

Mohammadi, M., \& Yegane, M.E. 2018. IOT: Applied New Technology in Academic Libraries. International Conference on Distributed Computing and High Performance (DCHPC), 1-12. https:// www.academia.edu/39875574/IOT_Applied_New_Technology_in_Academic_Libraries.

Nakagawa, Y., Matsuda, Y., \& Ogi, T. 2016. Personalized Information Service Model that Reflects Individual's Will. Serviceology for Designing the Future, 329-44. https://doi.org/10.1007/9784-431-55861-3_23.

Neuman, D. 2008. Music Camp Politics in the Classroom: Music, Politics and Protest. Music and Politics, 2(2). https://doi.org/10.3998/mp.9460447.0002.205.

Ni, M., \& Zhang, Y. 2019. Development of Mobile Library Based on the Internet + in China, 265-68.

Noh, Y. 2015. Imagining Library 4.0: Creating a Model for Future Libraries. Journal of Academic Librarianship, 41(6): 786-97. https://doi.org/10.1016/j.acalib.2015.08.020.

Pang, N., \& Yan, F. 2012. The Research on Personalized Service of Digital Library Based on Data Mining. Proceedings of the 2012 National Conference on Information Technology and Computer Science, CITCS 2012, 572-75. https://doi.org/10.2991/citcs.2012.221.

Petticrew, M., \& Roberts, H. 2008. Systematic Reviews in the Social Sciences: A Practical Guide. Systematic Reviews in the Social Sciences: A Practical Guide. https://doi.org/10.1002/9780470754887.

Prasetyo, E., et al. 2016. Model Bibliografi Berbasis Linked Data Pada Perpustakaan Digital. Makalah Seminar Nasional Teknologi Informasi Dan Multimedia Yogyakarta, 109-14.

Ridley, D. 2012. The Literature Review: A Step-by-Step for Students. London: Sage Publications.

Rowley, J. 2007. The Wisdom Hierarchy: Representations of the DIKW Hierarchy. Journal of Information Science, 33(2): 163-80. https://doi.org/10.1177/0165551506070706.

Santha, K.R. 2013. Mobile Phones: A New Dimension in Library Services. www.ceserp.com/cp-jour.

Sharman, A. 2014. Roving Librarian: The Suitability of Tablets in Providing Personalized Help Outside of the Traditional Library. New Review of Academic Librarianship, 20(2): 185-203. https://doi. org/10.1080/13614533.2014.914959.

Singh, K., \& Nikandia, P.K. 2017. Role of Mobile Technology and Their Application in Library Services in Digital Era. Journal of Library \& Information Science, 7: 157-66.

Stojanovski, J., \& Papić, A. 2012. Information Services in Academic Libraries: Browsing Services vs Searching Services, 85-90.

Taylor, K., \& Corrall, S. 2007. Personalized Service? Changing the Role of the Government Librarian. Journal of Information Science, 33(3): 298-314. https://doi.org/10.1177/0165551506070728.

Tutu, J.M. 2016. Provision of Digital Reference Services in Academic Libraries in Kenya: A Review. Regional Journal of Information and Knowledge Management, 2(1): 16-28.

Wang, D.X. 2016. Information Service in the Big Data Era and Development Strategies for University Libraries, 664-68. https://doi.org/10.2991/sschd-16.2016.128. 
Wang, F. 2011. On Personalized Service of Mobile Phone Library Based on Contextual Model. Proceedings - PACCS 2011: 2011 3rd Pacific-Asia Conference on Circuits, Communications and System, 0-3. https://doi.org/10.1109/PACCS.2011.5990178.

Wang, X., Li, J., Yang, M., Chen, Y., \& Xu, X. 2018. An Empirical Study on the Factors Influencing Mobile Library Usage in IoT Era. Library Hi Tech, 36(4): 605-21. https://doi.org/10.1108/LHT01-2018-0008.

Wang, X., Yang, M., Li, J., \& Wang, N. 2018. Factors of Mobile Library User Behavioral Intention from the Perspective of Information Ecology. Electronic Library, 36(4): 705-20. https://doi.org/10.1108/ EL-03-2017-0046.

Wei, Q., \& Yang, Y. 2017. WeChat Library: A New Mode of Mobile Library Service. Electronic Library, 35(1): 198-208. https://doi.org/10.1108/EL-12-2015-0248.

Zhang, Q. \& Wang, X. 2014. Digital Library of Personalized Information Services Approach and Countermeasures. Proceedings of the 2014 International Conference on Education, Management and Computing Technology 100 (Icemct): 404-6. https://doi.org/10.2991/icemct-14.2014.96.

Zhao, Y., Deng, S., Gao, T., \& Zhou, R. 2016. Research on User Needs for Mobile Information Services in Chinese University Libraries: Comparison between Existing and Potential Users. Electronic Library, 34(4): 617-35. https://doi.org/10.1108/EL-12-2014-0222. 